\title{
Hermenêutica e literatura: a metáfora em Paul Ricoeur como princípio de interpretação da poética em $O$ Guesa, de Sousândrade
}

Rita de Cássia Oliveira*

\section{Resumo}

É na obra La métaphore vive (1975) que Ricoeur trata da poesia como objeto de análise e interpretação. Ele procura instituir e legitimar, no âmbito da inovação semântica, a referencialidade do uso da linguagem poética numa relação de pertencimento: poesia e mundo e mundo e poesia. Isso porque é suposto que o poema projeta um mundo a uma dimensão ontológica, um ser-como, um ser estruturalmente dialético. $\mathrm{O}$ poema tem um poder de referenciação direta que decorre da equivalência subsumida pelo verbo "ser" em posição metafórica entre o ver-como da metáfora e o ser-como da própria realidade. É com esse princípio estético que interpreto o poema $O$ Guesa, de Sousândrade. As metáforas são recorrentes em $O$ Guesa para transportar imagens e ações que, numa transgressão das palavras, implodem com a linguagem, revelando uma narração autônoma em seus cantos.

Palavras-chave: Metáfora. Poema. O Guesa. Ricoeur. Sousândrade.

\section{Introdução}

\section{Metáfora e poesia}

A poesia não é o ponto de partida do projeto filosófico de Paul Ricoeur (19132005); o desenvolvimento desse projeto mostra que é a maneira como o autor concebe o ser da linguagem que o faz perpassar pela poesia como um processo de legitimação constitutiva da metáfora, como caso exemplar de excesso de sentido da linguagem. Seguir a constituição da teoria da metáfora em Paul Ricoeur obriga a reconhecer que ela se enraíza no seu princípio hermenêutico da obra La métaphore vive (1975) (Metáfora

\footnotetext{
Doutora. Professora do mestrado acadêmico do Programa de Pós-Graduação em Letras da Universidade Federal do Maranhão (Ufma). E-mail: rcoliveira30@ yahoo.com.br
}

Data de submissão: mar. 2017 - Data de aceite: jan. 2018 http://dx.doi.org/10.5335/rdes.v14i1.6815 
Viva) e decorre da sua concretização, por meio do confronto entre o ponto de vista fenomenológico da significação e a posição estruturalista sobre a linguagem. Aliás, a linguagem é entendida enquanto dimensão de narratividade, por apresentar uma perspectiva de limitação, na medida em que evidencia que o discurso humano se inicia sempre in media res, $o$ que exclui as hipóteses de se atingir um saber absoluto e, na acepção positiva de permissão, de se articular a experiência da temporalidade e da força persuasiva da argumentação.

A chave de compreensão do discurso poético em Ricoeur reside no princípio hermenêutico da distinção entre semiótica e semântica, por evidenciar o excesso de sentido dado pela pertença da metáfora. ${ }^{1}$ Com efeito, é a frase ou o enunciado a unidade linguística mínima de referência, por receber a reverberação total do excesso de sentido que a metáfora lhe imprime. É a frase ou o enunciado que permite a Ricoeur reintroduzir a questão da referencialidade da linguagem poética - a referência ao mundo e ao sujeito que fala - a partir do próprio terreno do estruturalismo, porque se atém ao contributo da investigação das ciências humanas, nomeadamente a linguística estrutural, para a compreensão da natureza da linguagem poética, segundo os parâmetros da fenomenologia. ${ }^{2}$

A linguagem poética é interpretada a partir de dois movimentos, articulados da composição de uma lógica de constituição de a síntese da linguagem poética ser linguagem plena, aquela dos símbolos, das metáforas e dos mitos. Eles são: por um lado, a ideia de ser a linguagem poética hermética, o que exige a análise do sentido dos valores ${ }^{3}$ diferenciais das palavras no sistema simbólico que é a própria língua.

Por outro lado, Ricoeur concebe uma interpretação em que o sentido transcende o signo e a referência, por considerar a subjetividade como o lugar de emergência da significação enquanto intenção de um sujeito. Neste ponto, Ricoeur coloca-se fora da posição estruturalista que entende a significação sem pertencer ao âmbito da intencionalidade do sujeito.

Segundo Ricoeur, a metáfora cria uma outra semântica, quando deslocada da palavra, mais precisamente atribuída ao nome, na teoria da significação, para a frase, na teoria da Filosofia da Interpretação, sendo a frase considerada como primeira unidade de significação. A metáfora atribuída ao nome é concebida como um tropo, por ser um desvio que afeta a significação da palavra. $\mathrm{Na}$ teoria aristotélica, a metáfora possui dupla função: poética e retórica, localizando-se na quarta parte da léxis, ${ }^{4}$ isto é, no nome, que é definido como um som completo dotado de significação. Resulta que a teoria da significação primou seu centro na denominação, interferindo na arte da persuasão como um discurso que valoriza a palavra ornamentada, por se tratar de uma elocução fundamentada na teoria dos tropos. 
Essa teoria baseia-se na premissa de que certos nomes pertencem às coisas como próprios e, quando falta esse termo, quer por ausência, quer por escolha de caráter estilístico, recorre-se a um recurso de uso de um termo impróprio, para preencher a lacuna lexical; então, usa-se um termo impróprio ou figurado para substituir a palavra ausente. Esse termo utilizado é a metáfora que, tanto por ausência como por opção estilística, ornamenta o discurso sem proporcionar uma verdade, o que implica a falta de qualquer informação nova, ou seja, a metáfora não ensina e tem uma função meramente decorativa, tornando a Retórica um discurso belo, mas vazio de sentido e sem referência.

$\mathrm{Na}$ linguagem poética, a palavra, quando transporta a metáfora, pulveriza o seu efeito de sentido em toda a frase, com repercussão em toda a narrativa. A metáfora é vista como um fenômeno da linguagem, por introduzir a subjetividade na narrativa. Para Ricoeur, a narrativa poética correlaciona uma história e o caráter temporal da experiência humana sob a forma de necessidade transcendental, na medida em que a vida pressupõe o contar dela própria, para se autofazer como história e transformar o tempo em tempo humano por meio da voz narrativa que introduz a subjetividade na temporalidade. E o liame entre metáfora e tempo presume a mímesis como o meio de representação da realidade em uma temporalidade. A mímesis constitui a referência metafórica.

\section{A teoria da tríplice mímesis}

Em Ricoeur, a mímesis perfaz todo o percurso da via longa da hermenêutica em decorrência de o seu desdobramento seguir toda a trajetória de construção da narrativa de ficção. É em Temps et Récit I (1983) (Tempo e narrativa I) que o filósofo apresenta a sua teoria da tríplice mímesis. Tal designação significa que o processo pelo qual a ficção constrói ou compõe a intriga que sustenta a sua textualidade se desenvolve em três momentos, são eles: mímesis $I$, que é a prefiguração do campo prático, mímesis $I I$, que é a configuração do mundo ficcional, e mímesis III, que é a refiguração do mundo vivido. A mímesis II, por meio de uma atividade mediadora entre a montante da mímesis $I$ e a jusante da mímesis III, cria quase-coisas com a invenção do como se, instaurando o mundo poético em um percurso que vai do seu enraizamento ontológico até a sua destinação existencial.

Sobre isso, Ricoeur diz que se propõe a mostrar que a mímesis II tira a sua inteligibilidade da sua faculdade de mediação que consiste em fazer a condução da montante à jusante do texto, em transfigurar a montante em jusante por meio do seu poder de configuração. Assim, a teoria da tríplice mímesis perpassa a linguagem, desde o mito até o alcance da sua destinação inicial, que é o leitor. A linguagem como mediação humana e como o elemento ontológico 
do humano, porque o reino humano é o reino da linguagem, na medida em que é a linguagem "expressão" e expressão de alguém; isto é, a linguagem solicita o dizer, porque é o próprio dizer, e possibilita a temporalização do ser, que insurge no presente do discurso enquanto acontecimento do discurso. Trata-se, pois, de um dito do dizer que se impõe como uma instância discursiva, por ser um ato que alguém articula linguisticamente como uma experiência que deseja partilhar. Ricoeur, pela teoria da tríplice mímesis, explicita o princípio hermenêutico da compreensão da linguagem.

Uma distinção que a hermenêutica fenomenológica considera no estruturalismo é entre a semiótica e a semântica. ${ }^{5}$ Essa distinção leva a encontrar na frase ou no enunciado a unidade linguística mínima de referência. É a frase ou o enunciado que vai permitir a Ricoeur introduzir a questão da dupla referencialidade da linguagem: a referência ao mundo e ao sujeito que fala a partir do próprio terreno do estruturalismo. Assim, a frase, enquanto realização efetiva da virtualidade da língua, faz a articulação entre estrutura e função ou entre sistema e acontecimento, realizando o quadrilátero discursivo: alguém diz alguma coisa a alguém sobre alguma coisa. Por isso, a frase, além de ser concebida como uma pura unidade semiológica, tem de ser vista como uma unidade semântica.

Ricoeur diz que o problema semântico distingue-se precisamente do proble- ma semiológico no fato de que o signo, constituído pela diferença, é revestido para o universo por via da referência. Ou seja, ao nível do plano semiótico, o nosso movimento linguístico se dá num sistema de diferenças; quando se desloca o olhar para o plano semântico, entra-se na função significante ou representativa da linguagem em que um signo remete para um real.

É também a questão da frase ou do enunciado que se constitui em mediação para a reintrodução da problemática do sujeito. E Ricoeur apropria-se da temática dos pronomes pessoais de Émile Benveniste no contexto do horizonte fenomenológico, para explicitar a presença da subjetividade na linguagem. Os pronomes pessoais - eu, tu, ele ou ela - são fatos da língua, definindo-se por relação de oposição (eu e tu opõem-se a ele ou ela, como a pessoa à não pessoa, e opõem-se entre si como emissor e receptor). Adverte-se que o sentido do "eu" não se esgota nessa listagem de oposições. O "eu", para Ricoeur, designa o indivíduo que enuncia a presente instância de discurso, contendo a instância linguística "eu".

Porém, o pronome pessoal "eu", por estar disponível na Língua, pode ser apropriado por qualquer indivíduo, o que releva a sua característica de signo vazio, enquanto pura disponibilidade, que só será preenchido quando um determinado indivíduo apreender este signo vazio ao designar-se a si mesmo como "eu", mediante um discurso que efetivará a virtualidade da Língua. ${ }^{6}$ Entretanto, para 
que Ricoeur possa assegurar a separação entre semiótica e semântica solicitadas pela frase, enquanto concebida como unidade linguística mínima, terá que não aceitar o "eu" como simples criação da linguagem, mas como a capacidade do locutor de se posicionar como sujeito e de se opor a outrem como interlocutor, sendo o pressuposto extralinguístico do pronome pessoal. Desse modo, Ricoeur afasta-se de Benveniste para conceber a linguagem como mediação e como meio nos quais e pelos quais o sujeito se põe, e o mundo se mostra. Afasta-se ainda do estruturalismo, ao conceber a significação nos âmbitos dos visados intencionais de uma subjetividade.

Com efeito, a hermenêutica de Ricoeur reveste-se de urna fenomenologia e passa a considerar estas três teses sobre a significação: 1) a significação ser a categoria mais englobante da descrição fenomenológica; 2) o sujeito ser aquele que transporta ou sustenta a significação; e 3) a redução ser o ato filosófico fundador da emergência de um ser como significação. Ricoeur ainda acrescenta que essas três teses se estruturam de modo a poderem ser percorridas nos dois sentidos: da primeira para a terceira e vice-versa. Da primeira tese para a terceira, tem-se a ordem da descoberta ou da constituição da posição fenomenológica. Já, da terceira tese para a primeira, está a ordem da fundação. Daí o filósofo dizer que é por meio da redução que aparece a nossa relação ao mundo; é na redução e por ela que todo o ser emerge na des- crição como fenômeno, como aparecer, portanto, como significação a explicitar, e ainda acrescenta que a significação é a mediação universal entre o sujeito e $o$ mundo. A perspectiva fenomenológica de Ricoeur diferencia-se da tradicional naquilo que faz a redução fenomenológica passar pela mediação dos signos, não se articulando tão somente nos termos da dicotomia entre consciência e mundo. Para tanto, busca na linguística e na semântica os meios de compreensão da função simbolizadora da linguagem, a qual se revela como a origem e não como uma consequência da vida social.

A linguagem, mais do que descrever a realidade, revele-a e cria-a por meio da narratividade. $\mathrm{E}$ a narratividade apresenta-se como o aspecto da linguagem que revela o seu sentido autónomo, na medida em que lhe confere à condição humana a temporalidade, enquanto capaz de orientar o sujeito em direção à interpretação de sua condição efetiva de ser no mundo, por exigir o ato de recontar. Ricoeur elabora uma teoria da narratividade em Temps et récit (1983; 1984; 1985), como uma correlação de base ao arcabouço de sua filosofia hermenêutica. Na teoria, a narrativa é compreendida como o emprego da linguagem que pressupõe uma "unidade funcional" à organização narrativa da experiência humana, que em sua natureza é fragmentada e dispersa. Essa "unidade funcional" que ordena o recontar da experiência humana é o tempo. O filósofo encontra-se em um estágio de 
conhecimento social em que se atesta a certeza da impossibilidade de expressão da experiência temporal pelo discurso descritivo do tipo científico, quer pela física, pela biologia, pela sociologia ou pela psicologia. Para Ricoeur, a especulação cosmológica empreendida por filósofos como Kant, em Estética transcendental (1985), Husserl, em Ideias para uma fenomenologia pura e para uma filosofia fenomenológica (2006), e Heidegger, em Ser e tempo (1993), também não consegue apreender tal experiência.

E Ricoeur volta-se para a linguagem indireta, a empregada pela literatura, como sendo a linguagem capaz de mediatizar o fenômeno do tempo, porque a experiência filosófica de especular o tempo se apresenta como insatisfatória na medida em que o tempo apresenta uma dupla natureza: exterior (física) e interior (vivida). O tempo físico pode ser medido pelo mostrador do relógio, porém o tempo que aparece na memória ou na imaginação jamais poderá ser mensurado, além de a semiótica já ter comprovado que não há relações necessárias entre as leis internas do discurso com a temporalidade. O tempo só pode ser compreendido como um elemento estrutural do texto. Ricoeur empreende uma pesquisa sobre uma noção de tempo para desenvolver a sua teoria da narratividade e poder compreender como a literatura apreende o fenômeno da temporalidade em relação com a teoria da tríplice mímesis, porque deseja recuperar a ideia aristotélica da mímesis como um trabalho de transformação e elaboração. Porém, diferentemente de Aristóteles, que a concebia como um processo único, Ricoeur percebe-a como um processo complexo que abarca a operação pela qual a experiência mimética se constitui numa totalidade que alcança obras, autores e leitores, tendo a sua reconstrução por meio do arco da hermenêutica.

Por isso, a formação do par mímesis-mythos traduz o ato poético como um trabalho de produção e simbolização pelo sujeito no tempo, que encontra a sua melhor expressão na metáfora, a qual interfere também na percepção da verdade, por desvelar uma realidade em que o conceito empírico de verdade-verificação não corresponde mais a esta realidade refigurada pela narrativa poética, sendo necessário o desencadeamento de um processo de intelecção da verdade como desocultação, uma experiência vivenciada pelos gregos antigos que a nomearam de alétheia.

\section{A metáfora no poema O Guesa}

A narrativa poética refigura a realidade por meio da tessitura da intriga em um ponto de intersecção que ata metáfora, mythos e mímesis, segundo uma experiência que solicita memória, imaginação e entendimento na constituição de uma forma de identidade pela palavra, a qual Ricoeur denomina de identidade narrativa. É partindo 
desses princípios que compõem a teoria hermenêutica de Paul Ricoeur que interpreto determinadas categorias filosóficas, identificadas na constituição da narrativa do poema O Guesa, de Sousândrade. Inicialmente, procuro apontar o sentido da metáfora no referido poema, porque ela transmite uma experiência por meio de uma presença inarticulada de um excesso de sentido que impulsiona uma dinâmica, arrancando os significados já constituídos na sua situação ordinária e transferindo-os para um novo campo referencial. As significações são libertadas da sua primeira fixação para um referente "desconhecido", outorgando à intenção semântica a "veemência ontológica". As significações não são formas estáveis. Elas são, na realidade, dotadas de uma capacidade de variação e de um dinamismo que lhes possibilitam servir a outros referentes e cooperar na inovação semântica. Como é o caso desta passagem, no Canto Primeiro, em O Guesa, no qual Sousândrade utiliza primeiramente a metáfora do Lethes, que na mitologia grega representa o rio do esquecimento. Ora, o Lethes é, pois, um rio da morte, já que quem bebia das suas águas adentrava no reino das sombras, porque perdia a lembrança e a consciência.
Contemplação nas sombras

"Não fostes ainda o Lethes... Aqui, d'onde

Veloz gavião-real, predendo a cobra

Que esfuzia e debate-se, desdobra"

No ar as azas serenas e respondendo

"Com grita ovante ao s'escorjar violento

Do réptil, sobre o espaço ora sedento

E lívido o seguindo e o retomando" -

"À dor sua abraçada, no martyrio

Do que dobra ao bater do pensamento

E não pré-sente vir-lhe o esquecimento

Nem dos céus, nem da morte ou do delírio",

"O homem descansa. Uma ave se desata

E desdenha ao rochedo; e elle ahi, preso

Pelas cadeias do seu próprio peso

Une-se à terra... condição ingrata!"

"Oh, ironia!" O fazem miserável

E abrem-se os olhos! Para que? (SOUSÂN-

DRADE, 2003, p. 125).

Mas o rio Solimões, em cujas margens o Guesa se encontra, não é o Lethes, por isso não leva ao esquecimento daquele ato atroz de violentação, ao qual estão sendo submetidos os índios pela colonização espanhola. O que Sousândrade estava querendo esquecer? É uma pergunta que se levanta na interpretação, indagando sobre os aspectos subjetivistas do poema, uma vez que Sousândrade era adepto do regime republicano e tinha uma proposta de política educacional para o povo autóctone. A interpretação hermenêutica abre muitas variantes de interpretação que enriquecem a leitura sem, no entanto, perder o lastro metodológico de análise dos símbolos presentes no texto poético de cunho hermético. Tanto é assim que Sousândrade incorpora a esse aspecto simbólico da sua ideologia independentista republicana a figura-símbolo que 
representa o mundo asteca: o gavião-real prendendo a cobra no bico, símbolo que representa o brasão de armas na bandeira do México. Observa-se, no entanto, que na bandeira do México o elemento alado é uma águia, que Sousândrade mudou para a figura do gavião-real. O certo é que essa referência serve para enaltecer a lenda asteca do descobrimento da cidade do México. Essa lenda conta que os astecas, um povo nómade, encontravam-se a vaguear em busca de um sinal que lhes indicasse o local exato em que deveriam construir a sua capital. Então, o deus da guerra, Huitzilopochtli, ordenou-lhes que procurassem uma águia pousada em cima de um cacto que crescia sobre uma rocha submersa num lago. A águia portaria, no bico, uma serpente que teria acabado de caçar. Somente após duzentos anos de perambulação, o povo encontrou o sinal prometido numa pequena ilha pantanosa no lago Texcoco.

Em seguida, Sousândrade recorre novamente a outro elemento clássico da mitologia grega, a figura de Prometeu acorrentado no alto da montanha e torturado por um abutre a lhe bicar o fígado, imediatamente refeito para, em seguida, ser novamente devorado. Prometeu foi tema favorito dos poetas do século XIX, aparece em Milton, Byron e Shelley, passando a ter na tradição romântica uma revalorização cristã, quando é comparado a Cristo na cruz. E, para Sousândrade, o Guesa é Prometeu e Cristo, enquanto índio subjugado pelos seus inimigos.
O poeta considerava que esses elementos culturais e sociais, indígena, clássico e judaico-cristão, pudessem representar o seu sentimento de desolação frente à situação vivida pelo ameríndio. Percebe-se de modo claro o sincretismo sousandradino na intercalação de imagens que se sobrepõem para dizer de uma América que urge, segundo o poeta, por um regime republicano in toto harmonioso, em que a sua verdadeira essência fosse pautada por esses três elementos.

Ricoeur, no livro La métaphore vive (1975), diz que as imagens poéticas não se destacam apenas pelas qualidades vívidas. Quaisquer que sejam as metáforas usadas, por meio delas, facilmente se perceberá que as imagens poéticas servem não apenas de simples ornamentação, são também, todas elas, destinadas a exprimir os melhores sentimentos que não carecem de um longo desenvolvimento. $\mathrm{O}$ que leva a pensar que a metáfora poética merece ser estudada por si mesma e tem identidade própria em razão de sua exterioridade significante.

Continua Ricoeur: não há nada mais clássico que essa teoria "econômica" da metáfora, que prega ser ela uma figura da linguagem que detém uma riqueza de sentido numa única palavra e, por isso, possibilita a economia de um longo desenvolvimento do discurso. Com efeito, a metáfora e outras figuras, notadamente a comparação, seriam homogêneas, não poderiam ser distinguidas pelo grau de 
ampliação do seu sentido. A mais breve das figuras de palavra, a metáfora, seria também a mais geral e responsável pela economia de todas as outras figuras de palavras. Essa teoria pode ser creditada a Aristóteles.

No entanto, Ricoeur concorda ser a comparação (ou imagem: eikôn) também uma metáfora; a diferença é mínima, porque, segundo ele, quando Homero, ao falar de Aquiles, diz "que este se transporta como um leão", ele faz uma comparação (eikôn); quando ele diz que "é um leão" que se transporta de um lugar a outro, é uma metáfora. Ricoeur diz que o propósito de Aristóteles não foi explicar a metáfora pela comparação, mas, explicar a comparação pela metáfora, e acentua que a metáfora por comparação não é uma formulação simples, como quando chamamos "Aquiles de leão": a simplicidade da comparação, por contraste com a complexidade da proporção de quatro termos, a mesma para que tende a metáfora proporcional como quando dizemos: "Le bouclier est la coupe d'Ares" (O escudo é a taça de Ares). Dessa maneira, a metáfora por analogia tende a identificar-se ao eikon, e a supremacia da metáfora sobre o eikon é, se não invertida, pelo menos modificada, porque o eikon se "dit toujours à partir de deux, comme la métaphore par analogie, que le rapport peut être si facilement inversé" (RICOEUR, 1975, p. 36-37).

Em Sousândrade, identifica-se a metáfora por analogia no uso do pronome relativo "qual", em que a comparação é estabelecida por relação de identidade, como ocorre no seguinte verso: "Negra, negra eu sou, mas formosíssima / Qual as tendas brilhantes de Kedar!" (2003, p. 95). Para Ricoeur, o traço determinante da comparação é o seu caráter discursivo, porque, para comparar, são necessários dois termos igualmente presentes no discurso. Ricoeur diz que o linguista I. A. Richards ${ }^{7}$ conceitua a metáfora como uma construção resultante de duas ideias: tenor e vehicle, equivalendo, respectivamente, à "ideia original" e à "ideia tomada de empréstimo", ou seja, aquilo que está sendo dito ou pensado e aquilo com que está sendo comparado. A interação do designatum e do veículo geraria um novo sentido, diverso daquele que cada ideia apresenta isoladamente; e a medida de sentido se imporia como resultante de características comuns a ambos os sentidos, resultando na construção da metáfora.

Porém, a análise gramatical da comparação assegura a sua dependência em relação à metáfora em geral, apenas diferindo uma da outra pela presença ou pela ausência do termo da comparação. Para Aristóteles, a ausência do termo de comparação na metáfora não implica que a metáfora seja uma comparação abreviada, mas, pelo contrário, que a comparação é uma metáfora desenvolvida. Ora, a comparação diz "isto é como aquilo"; e a metáfora diz "isto é aquilo".

Em Sousândrade, a comparação, por exemplo, entre o nascer do dia com o reflexo da luz através de uma porcelana 
ocorre novamente por meio do pronome relativo "qual", para imprimir na ideia tomada de empréstimo o sentido da ideia original, constituindo uma imagem rica de associações, como nos versos do Canto Segundo: "Qual um vaso de fina porcelana / Que de através o sol alumiasse, / Qual os relevos da pintura indiana / É o oriente do dia quando nasce" (SOUSÂNDRADE, 2003, p. 35). Já a metáfora aparece como uma contenção de ideias em que se torna necessário o conhecimento da significação da ideia originária, para que se possa decifrar a ideia resultante do deslocamento da palavra. Como é o caso em que Sousândrade denomina D. Pedro II como o Fomagatá, o espírito do mal para o povo Muíscas, segundo a lenda do Guesa descrita por Famin e assimilada pelo poeta na seguinte passagem:

(Ruge do coração do Guesa a história)

Os captivos choravam da Victoria,

Quando voz de consolo ouvi de meu irmão:

Porque desesperar? Filho do império,

Temos nós um monarcha verdadeiro,

Das lettras protector, um grande coração.

De um palácio as escadas eu subindo,

Bem vi publicamente destribuindo

Moedas de oiro e úa mão sabendo que outra dá:

Eu quis voltar; e andando, andei p'rá deante.

Veiu então paternal, o ar elegante,

Deu-me a mão... - será Fomagatá...? (SOU-

SÂNDRADE, 2003, p. 138).

A metáfora em Sousândrade é necessária. Ela é concebida como um processo radical em que são atadas as relações internas da poesia. Para o poeta, a metáfora é a atualização das potências con- tidas na faculdade imaginativa, porque, pela metáfora, ele quebra a simplicidade fatual da linguagem, dimensionando-a para um "dizer" poético que redescreve a ação humana. Assim, o elemento comum à metáfora e à comparação é a assimilação que funda a transferência de uma denominação, isto é, a identidade captada na definição de dois termos. Aristóteles diz que é a apropriação do gênero por meio da semelhança que torna a metáfora instrutiva. E o que define o espaço atribuído à metáfora na transferência de uma ideia primitiva para uma ideia nova é a semelhança.

Segundo Ricoeur, a linguística estrutural simplificou ao máximo o quadro dos tropos, até o ponto em que restaram a metonímia e a metáfora, isto é, a contiguidade e a semelhança. A "correspondência" que está na base da metonímia aproxima as ideias de objetos que constituem, em si, totalidades absolutamente diferentes, mas a pluralidade das relações que satisfazem essa condição geral não se reduz à contiguidade. No que diz respeito à relação de "conexão" que abrange a ideia de inclusão de duas coisas num todo, opõe-se à ideia de relação/correlações, que implica uma certa exclusão mútua de termos ligados. $\mathrm{E}$, nessa sequência, a semelhança é confirmada pela operação de simplificação que faz dela o único correlativo de um único oposto: a contiguidade. Mas, o mais importante nesse assunto foi feito por Roman Jakobson no seu artigo de 1953, "Dois aspectos da linguagem e dois 
tipos de afasia" (Deux aspects du langage et deux types d'aphasie), publicado na obra Linguística e comunicação (2006), que ligou essa dualidade tropológica e retórica a uma polaridade mais fundamental, que não diz respeito apenas ao uso figurativo da linguagem, mas ao seu próprio funcionamento.

Para Jakobson (2006), o metafórico e o metonímico, além de qualificar figuras e tropos, qualificam processos gerais da linguagem. Ao generalizar a distinção do metafórico e do metonímico para além da tropologia e, logo, para além da transformação do sentido das palavras, ele reforçou a ideia de que a substituição e a semelhança são dois conceitos inseparáveis, uma vez que se estabelecem numerosos níveis de efetuação da linguagem. Isso fica muito claro na arte da linguagem, em que a interação da metáfora com a metonímia é particularmente marcante, veja-se nestes versos em $O$ Guesa:

Do sol oblíquo o raio, prolongada

Vai dos troncos a sombra silenciosa:

Em tarjas de oiro e negras, a esplanada

Abriu da tarde a página saudosa.

Vem perto a noite - e inda não era dia...

Já é a tarde - eram então albores...

Pois que esta alma s'eleva na harmonia

Da rosea tarde e das ethereas flores! (SOUSÂNDRADE, 2003, p. 85).

Percebe-se que a relação entre a metáfora e a metonímia ocorre num paralelismo entre versos sucessivos, segundo uma correspondência do nível verbal - morfológico, léxico, sintático e fraseológico -, com a similaridade e a contiguidade aparecendo e formando uma gama de configurações possíveis, em que pode prevalecer uma ou outra. $\mathrm{O}$ processo metafórico na poesia predomina nas escolas romântica e simbolista, já na corrente literária realista é preponderante a recorrência às metonímias.

É na poesia que se encontra o verdadeiro lugar da metáfora. Por isso, torna-se importante o poema $O$ Guesa, para uma averiguação do poder de excesso de sentido que detém a metáfora. Tanto é assim que a figura linguística exerce o poder de aproximar noções incompatíveis, funcionando para além de uma simples supressão de palavras e de um meio de introduzir aproximações sucessivas, ao contrário, proporciona imagens fabulosas e uma insurreição sonora tanto quanto os efeitos melopaicos, causados pela introdução de esquemas fonéticos.

Augusto e Haroldo de Campos destacaram esses efeitos melopaicos em $O$ Guesa como resultantes da combinação métrica dos versos, como pura musicalidade originada por:

[...] uma calculada alquimia de vogais e consoantes, num sentido de harmonização pré-simbolista, de "poesia pura", como incorporar a dissonância e o contraste, o choque e a aspereza. É uma arte que não se volta apenas para o acorde, mas se deixa torturar até a ruptura ou explosão pelo sentimento do desacorde (CAMPOS, A; CAMPOS, H., 2002, p. 91, grifo do autor).

Essa musicalidade é perfeitamente percebida nos versos a seguir: 
Meia noite! O Guesa Errante

(Na selva os berros do jaguar fragueiro, Nas plúmbeas praias da deserta Ronda Colhendo o lanço os ledos marinheiros), Do seu banho noctuno agora da onda

Se separava. Assobiando os ventos

Nas encostas sonoras, lhe enxugavam

Os negros cabellos, que agitavam

Qual ondulam sombrios movimentos

Sobre os Sollimões pallido. Elie escuta:

Auras surdas; diaphanas alfombras

No espaço; o resomnar de pedra bruta;

E entristeceu (SOUSÂNDRADE, 2003, p. 9).

Os sons são ouvidos na imaginação de quem os lê. E os tons do acorde e do desacorde são nitidamente distinguidos no substantivo "os berros do jaguar fragueiro" em relação com o verbo "Assobiando os ventos"; nos adjetivos: "nas encostas sonoras"; e "Auras surdas". O contraste dos termos usados para expressar a empiria da realidade imprime o desacorde entre o real e a ficção, entre o grito e o murmúrio numa musicalidade que completa o itinerário da sonoridade imagética do poema. O som é percebido na faixa semântica em que os símbolos verbais indicam referentes que podem ser chamados de "valores sonoros". Os signos metafóricos em Sousândrade tendem a reconhecer o nível do referente empírico nas imagens da natureza (tão prementes no poema), segundo uma transmutação em correlato objetivo de uma experiência subjetiva. Assim, substantivos, adjetivos, verbos ou advérbios fazem referência a fenômenos acústicos, funcionando como "som" no processo da narrativa.
Esses "valores sonoros" se alternam de acordo com a imagem criada, para introduzir a noção de movimento ao poema. O movimento é marcante. E é percebido pela mudança da descrição da natureza, de acordo com o lugar onde se encontra o herói Guesa. O movimento é percebido tanto na natureza, "O oceano trazia-o com o egoísmo", como na alma do Poeta-Guesa, "E canta... a Voz às noites incantadas". Novamente o objetivo se transmuta em subjetivo, numa alternância que veicula por si mesma a ideia de movimento, principalmente considerando que o poema trata de um périplo feito por Sousândrade, tanto pelo continente americano como pelo interior de sua alma.

\section{Considerações finais}

Em Aristóteles, a poesia é a imitação da ação humana. A contextualização dessa imitação em arte, no entanto, exige a passagem pela criação de uma fábula, de uma intriga que envolva paixão e desatinos sobrepujantes aos dramas quotidianos da vida. A ação humana, assim, reveste-se de metaforicidade. Esse caráter da poesia lhe é dado pela mímesis. Essa transmutação da ação em poesia por meio da mímesis foi elaborada de modo magnífico por Sousândrade, ao elevar para o plano do poético a dimensão mítica da lenda dos índios da Colômbia, os Muíscas. A lenda apresenta a estrutura do arquétipo da América na mais antiga concepção mítica de um povo, que é da 
transmigração da alma pelo sacrifício da inocência em oferenda a um deus.

A lenda do Guesa compõe-se da magnitude e do mistério contidos no mito de todas as culturas arcaicas, o que dimensiona o poema $O$ Guesa numa perspectiva universal, cósmica, em que o maravilhoso se afigura nos símbolos da natureza, segundo uma representação moral do bem e do mal, nas peripécias dos atos do herói na sua longa trajetória. A lenda narra a peregrinação do ritual vivido pelo Guesa. Sousândrade inicia o seu poema $O$ Guesa com a citação da lenda, conforme apresentada na enciclopédia L'Univers:

"La victime était un enfant enlevé de force à la maison paternelle, dans um village du pays connu aujourd'hui sous le nom de SAN JUAN DE LOS LLANOS. C'était le guesa, ou l'errant, c'est-à-dire la créature sans asile; et cependant on l'élevait avec un grand soin dans lê temple du soleil jusqu'à ce qu'il eût atteint l'âge de quinze ans. Cette période de quinze années forme l'indiction dite des muyscas". "Alors le guesa était promené processionnellement par le suna, nom donné à la route que Bochica avait suivie à l'époque ou il vivait parmi les hommes, et arrivait ainsi à la colonne qui servait à mesurer les ombres équinoxiales. Les Xeques ou prêtres, masques à la manière dês Egyptiens, figuraint, le soleil, la lune, les symboles du bien et du mal, les grands reptiles, les eaux et les montagnes".

“Arrivée à l'extémité du SUNA, la victime était liée à une petite colonne, et tuée à coups de flèches. Les XÈQUES recueillaient son sang dans des vases sacrés et lui arrachaient le coeur pour l'offrir au soleil". - L'Univers, Colombie” (SOUSÂNDRADE, 2003, p. 26).

Sousândrade encontrou na lenda do Guesa a base antropológica mais antiga da América pré-colombiana, concebendo a lenda na realidade pré-colombiana e transformando-a para uma história do continente americano. Segundo Sebastião Duarte (2002), é por meio desse artifício que o poeta rompe com a visão de uma América cindida em duas - uma, a europeia, invasora, mas ilustrada; outra, a autóctone, invadida, mas ignorada. $\mathrm{O}$ poeta cria as condições para assentar o plano maravilhoso de sua invenção, partindo para construir o respectivo plano histórico.

O enlace entre o plano do maravilhoso e o plano do histórico na lexis poética ocorre por meio da "epífora do nome", já dizia Aristóteles. A epífora é a noção de movimento que decorre quando se emprega o deslocamento "de... para". Em Aristóteles, a epífora é a metáfora, pela 
transposição de sentido que o deslocamento de uma dada palavra proporciona, quando é retirada do seu lugar linguístico original para outro lugar linguisticamente diferente. A epífora demanda uma informação e afeta o sentido da admiração, por acrescentar, como extensão maior ao sentido do termo, a noção de perplexidade. A epífora é a metáfora e liga-se à poética "non pas au niveau du discours, mais au niveau d'un segment de discours, le nom" (RICOEUR, 1975, p. 20). Isso porque Aristóteles considera a análise da elocução em partes, aparecendo nitidamente o nome como o eixo central da enumeração que é definido como "um som significativo, composto, sem determinação de tempo, que não tem nenhuma parte que, como parte do todo, seja significativa de per si [...]" (ARISTÓTELES, 1973, p. 190). O nome é a primeira das entidades enumeradas dotadas de significação. A teoria da lexis pela sua análise em partes tem o objetivo, em Aristóteles, de destacar o núcleo semântico comum a todas as outras partes e de acentuar aquela que seria a parte central, isto é, o nome, por ter este a função-pivot. Aristóteles questiona:

Qual o nome corrente, ou nome insigne, ou metáfora, ou nome de ornamento, ou nome formado pelo autor, ou nome alongado, ou nome encurtado ou nome modificado? (1973, p. 220).

E responde que a metáfora é algo que acontece ao nome, e dois são os traços que a caracterizam, o primeiro é chamado de "desvio", e o segundo, por postular o "processo", permite um uso livre. Porém, chama-se atenção para o fato de que um desvio imposto pela língua, um uso forçado, não fará jus ao nome de metáfora, pois a noção de desvio traz consigo o sentido de extensão da expressão, quer esta seja palavra, frase ou discurso. E o uso livre, por um lado, implica o afastamento das expressões do seu sentido próprio, por outro, supõe que a expressão própria está disponível e pode ser substituída por outra de livre escolha.

Assim, nota-se a presença da epífora do nome em Sousândrade com o próprio emprego da palavra Guesa, que é uma metáfora e significa o "errante", o "sem lar"; carregando a simbologia da lenda de um índio escolhido desde a infância para, aos quinze anos de idade, cumprir a missão de garantir a continuidade de sua estirpe pelo sacrifício da própria vida. $O$ poeta faz o primeiro deslocamento de sentido da palavra Guesa quando altera o significado original, um menino índio órfão que vai viver longe dos pais, para o sentido que personifica todos os índios da América que viviam inocentes e felizes até serem despojados do seu paraíso natural com a invasão dos conquistadores europeus.

O segundo deslocamento remete para o "processo", com o acréscimo ao poema da história pessoal de Sousândrade, que, também órfão, passa a vida vagando pelo mundo, em eterno estado de incompreensão e solidão, procurando realizar o sonho de construção de uma república redentora em que vingassem a harmonia e a felicidade geral como missão de um "último guesa". 
O mito do Guesa tem como traço fundamental o caráter de ordem, organização e disposição, refletindo na composição dos versos do poema, apresentando um eco em toda a discursividade da ação, do caráter e do pensamento. O mito Gue$s a$ tem a exteriorização e a explicitação da sua ordem interna, por meio da lexis que apresenta a mímesis. E a função mimética na poesia é dada pela metáfora, constituída por uma dupla tensão, quando a mimesis representa as melhores ações: submissão à realidade e invenção fabulosa, por um lado, e restituição e sobrelevação ao maravilhoso, por outro. Agora, considerada formalmente enquanto desvio, a metáfora é somente uma diferença no sentido. E, enquanto vista de modo abstrato, fora da função mimética, a metáfora esgota-se na sua capacidade de substituição e dissipa-se no ornamento, perdendo-se nos jogos de linguagem.

A metáfora, recolocada sobre esse fundo da mímesis, perde todo e qualquer caráter gratuito. Ricoeur observa que não se poderia ligar ao traço da elevação do sentido, próprio da mímesis, uma relação de conveniência com o deslocamento de sentido próprio da metáfora, que se exerce a depender da função da palavra.

Para o filósofo, o conceito de mímesis serve de indicador para a situação do discurso, porque lembra que todo discurso insere a nossa pertença ao mundo. É pela mímesis que a lexis é enraizada. Todo discurso, segundo Ricoeur, está no mundo por perseverar a função referen- cial do discurso poético. "En tant que mímesis physeos, elle lie cette fonction référentielle à la révélation du Réel comme Acte" (RICOEUR, 1975, p. 71). A mímesis, assim, é o outro lado da poesia, porque revela a sua referência.

A interpretação do processo mimético em $O$ Guesa revela posições sociopolíticas e religiosas do seu autor, assim como um forte teor autobiográfico que expressa todo um estado de impacto vivido por Sousândrade ao presenciar a situação do índio da América em pleno século XIX, em que a tecnologia e a ciência avançavam inexoravelmente para a crença de que a sociedade evolui em estágios progressivos. ${ }^{8} \mathrm{E}$ a mimesis physeos insere-se no poema com as alusões aos elementos da natureza como signos de realidades física, psíquica e espiritual, o que torna razoável pensar que a natureza atua no poema não só como physis, mas também como correlato objetivo da subjetividade do poeta, sendo lícito se deduzir que isso se deve ao fato de que há momentos em que um fenômeno da natureza se liga, no corpo verbal do poema, a um fenômeno da "alma", como nos versos:

O tronco secular já não me entende A sombra docemente abaunilhada Nas calmas do verão;

A mim nos campos meus não se desprende Mais o róseo sorrir da madrugada; Eu olho o céu - o céu é solidão! (SOUSÂNDRADE, 2003, p. 132). 


\section{Hermeneutics and literature: the metaphor in Ricoeur as a principle of interpretation of poetics in $O$ Guesa, by Sousândrade}

\begin{abstract}
In the french book La métaphore vive (1975), Ricoeur treats the poetry as subject of analysis and interpretation. He tries to institute and legitimize, in space of semantic innovation, the referentiality of use of poetic language which is put in field of binary relation: poetry and world. That's why, it's supposed that poem projects a world to an ontological dimension, a "being-as", a structurally dialectical being. Poem has a power of direct referenciation which comes from the hidden equivalence of verb "to be" in metaphorical position between the seeing-as of metaphor and the being-as of own reality. That is the aesthetic principle that $\mathrm{i}$ use to interpret the brazilian poem $O$ Guesa written by brazilian poet Sousândrade. The metaphors are constant in $O$ Guesa. The are used to transport images and actions, that in a transgression of words, implode the language, revealing an autonomous narration in singigs of book $O$ Guesa.
\end{abstract}

Keywords: Metaphor. Poem. O Guesa. Ricoeur. Sousândrade.

\section{Notas}

1 É na distinção entre semiótica e semântica que se encontra a separação entre o paradigmático e o sintagmático. $\mathrm{O}$ paradigma corresponde ao semiótico, e a ele pertencem as flexões, as derivações e os signos no sistema. Ao sintagma pertence o próprio nome que possibilita alcançar o sentido da frase. A substituição faz parte da lei sintagmática e tem que ser colocada ao lado da semântica. Com isso, percebe-se que a me- táfora, quando tratada em termos de discursos, constitui-se em enunciado metafórico, sendo um sintagma, porque condiciona a ligação entre os elementos comuns presentes no enunciado. Essa condição faz com que a metáfora seja classificada ainda como semântica, por afetar o sentido entre as substituições, o que requer uma investigação semântica, porque visa à forma do discurso, logo, do sintagma realizado pela metáfora. Assim, é como sintagma que o enunciado metafórico deve ser considerado, em consequência de o efeito de sentido resultar de uma determinada ação que as palavras exercem umas sobre as outras.

2 Ricoeur (1986) diz que a fenomenologia tem a sua origem na descoberta do caráter universal da intencionalidade, porém sem "hipostasear" a subjetividade como tendo um sentido em si mesma, mas deslocando o eixo da interpretação da questão da intencionalidade da subjetividade para o mundo exterior pela mediação dos símbolos, signos e textos: "[...] não há compreensão de si que não seja mediatizada por signos, símbolos e textos; a compreensão de si coincide, em última análise, com a interpretação destas condições mediadoras entre a intencionalidade e o mundo exterior" (RICOEUR, 1986, p. 42). Esta mudança de eixo faz com que Ricoeur proponha uma fenomenologia hermenêutica, trabalhada no livro Du texte à l'action, em que levanta a tese de que a questão da intenção da subjetividade está subordinada à coisa do mundo. O texto é o que media com maior complexidade o mundo que apresenta e abre, mesmo que se considere símbolos e signos como meios entre a subjetividade e o mundo: "A mediação pelos textos parece restringir a esfera da interpretação à escrita e à literatura em detrimento das culturas orais. Isso é verdade. Mas o que a definição perde em extensão, ganha-o em intensidade. A escrita, de fato, abre recursos originais ao texto, por evidenciar o sentido da comunicação no primeiro instante da compreensão do dito de alguém para o seu outro na acepção primeira da frase em que alguém diz alguma coisa a alguém; depois, caracterizando-o pela composição das sucessões de frases em forma de narração, de poema ou de ensaio, ou seja, de um texto" (RICOEUR, 1986, p. 52).

3 Segundo Ricoeur (1985), a questão do valor linguístico é de fundamental importância, por se constituir no ponto mais original da teoria de Saussure ao introduzir o problema da iden- 
tidade linguística, isto é, a identificação de duas ocorrências de uma mesma expressão. Saussure verifica que não é por meio da consideração das substâncias psicológica e fônica que se dará o reconhecimento de duas ocorrências de uma mesma expressão, pois, levando-se em conta a execução individual, só se dará esse reconhecimento quando se toma por referência o seu valor, ou seja, a sua relação com os outros termos que formam o sistema: "O mecanismo linguístico gira todo ele sobre identidades e diferenças, não sendo estas mais que a contraparte daquelas" (SAUSSURE, 2006, p. 136). A teoria do valor enaltece o primado da palavra e estabelece que as unidades características dos diversos níveis de organização da linguagem dimanam de uma única ciência: a semiótica. Para Ricoeur, a preocupação dominante de Saussure foi identificar, definir e delimitar a unidade linguística de base, isto é, o signo.

4 Para Aristóteles, a elocução (lexis), ou as formas elocucionárias do discurso, refere-se às seguintes partes: a letra, a sílaba, a conjunção, o nome, o verbo, o artigo, a flexão e a proposição. A letra, sendo um som indivisível, é a primeira parte da elocução e provém da métrica. A sílaba é um som desprovido de significação própria; a conjunção é palavra destituída de significado próprio, mas que não obsta nem contribui para que vários sons significativos componham uma única expressão significativa; já o verbo é som significativo que exprime o tempo e cujas partes, como as do nome, fora do conjunto não têm significado nenhum. A relação do nome com o verbo constituirá a flexão, que será complexada na proposição que se define como um som complexo com significação complexa, cujas múltiplas partes possuem um sentido por si mesmo (ARISTÓTELES, 1987, p. 43-47).

5 A semântica, definida como a ciência da significação das palavras e das mudanças de significação das palavras, tem-se apresentado como semântica estrutural, que se edificou sobre o postulado da homogeneidade de todas as unidades da linguagem, enquanto signos. A semântica moderna, a partir de Ferdinand de Saussure, tornou-se capaz de dar fundamento novo à mesma descrição dos tropos, porque possui um conceito novo de entidade linguística de base, o signo. Para Ricoeur, o monismo semiótico tinha em Saussure os seus limites e diversas contraposições, mas, mesmo assim, radicalizou-se. Por isso a oposição no plano da metáfora entre uma teoria da substituição e uma teoria da interação reflete a oposição fundamental no plano dos postulados de base da linguística entre um monismo semiótico ao qual se detém a semântica da palavra e da frase e um dualismo do semiótico e do semântico, em que a semântica da frase se edifica sobre os princípios distintos de todas as operações sobre os signos. A tese central de Ricoeur em O conflito das Interpretações (1988) é que opor o signo ao signo é a função semiótica; representar o real pelo signo é a função semântica; mas a primeira está subordinada à segunda. A primeira é por causa da segunda, ou, se quisermos, é por causa da função significante ou representativa que a linguagem é articulada. É segundo essa distinção fundamental do semiótico e do semântico que vai se realizar a convergência típica de três domínios: o da linguística da frase ou da instância do discurso, o da lógica do sentido e da referência e o da fenomenologia da palavra. É aí que vai se distinguir o método de Ricoeur, que coloca que, sem a mediação do semiótico e do lógico, a filosofia da expressão e da significação nunca poderá transpor o limiar do semântico, que irá condicionar a inteligibilidade de sistemas semióticos e conferir, pela referência, sentido à distinção entre significante e significado.

6 Ricoeur observa que Benveniste sublinha que qualquer discurso produz-se como um acontecimento por se caracterizar em atos discretos e de cada vez únicos pelos quais a língua se atualiza em falas por um locutor, por isso a expressão "instância do discurso", forjada pelo linguista, para opor o discurso à língua, devido a esta ter na sucessão do tempo somente uma existência virtual, na medida em que ela existe propriamente, quando um locutor dela se apropria e a atualiza. E o discurso, que como acontecimento é transitório e fugaz, como fica a sua existência? A essa questão Benveniste responde que o discurso pode ser identificado e reidentificado por meio da expressão "mesmo" que introduz à sua significação uma identificação de unidade de discurso, por impor-lhe um sentido. Portanto, a instância do discurso é um acontecimento repetível. Além do mais, o discurso apresenta uma polaridade típica: função identificante $\mathrm{e}$ função predicativa - a primeira caracteriza-se pelo enlaço do nome e do verbo para formar o logos articulado. Por causa desse entrelaçamento, o discurso visa a alguma coisa e pode ser apreciado, enquanto verdadeiro ou falso. Essa polaridade do identificante e da função predica- 
tiva se apresenta, por um lado, nos individuais denominados como seres que existem, mesmo que essa existência seja neutralizada, como é o caso da ficção: sempre se fala de qualquer coisa que é, porque a noção de existência está ligada à função singularizante da linguagem, ora, os sujeitos logicamente próprios são em potencial existentes, daí a "aderência" da linguagem às coisas; por outro lado, na predicação de qualidade, temos as classes, relações e ações que são, de fato, universais que se referem a objetos empiricamente inexistentes. Então, não faz sentido perguntar se a felicidade existe, mas se um tal que é feliz existe.

7 Ricoeur (1975) acentua que I. A. Richards, no livro The Philosophy of Rhetoric, observa que as palavras não têm sentido próprio, porque não têm significação própria, na medida em que não possuem sentido em si mesmas. É o discurso que contém o sentido de modo uno, por ter um contexto pautado em si mesmo e de maior constituição, uma vez que é formado pela situação de pergunta e resposta. Já a palavra detém o seu sentido devido a um fenómeno de "eficácia delegada", que é a troca de significados das palavras que formam um contexto menor. $\mathrm{O}$ contexto de um discurso pressupõe um feixe de acontecimentos, que surgem conjuntamente, incluindo aí as condições requeridas, assim como o que podemos isolar como causa e efeito. Nessa perspectiva, há uma semântica da metáfora que se apoia na tese da interanimação das palavras no enunciado, por pregar a restituição das possibilidades interpretativas das palavras contidas no todo do enunciado. Com isso, a metáfora tem validade para todas as formas de duplo sentido, podendo ser ligada às intenções, às pressuposições e às convenções veiculadas pelas partes ausentes do contexto. Assim, a frase continua com prioridade em relação às palavras, e estas não se constituem como nomes das ideias presentes no espírito; elas reenviam o sentido para as partes ausentes do contexto do enunciado. Sendo que o enunciado metafórico não revoga a definição nominal da metáfora, uma vez que a palavra continua como portadora do efeito de sentido metafórico, permanecendo a definição de metáfora dada por Aristóteles.

8 A década de 1860 no Brasil foi marcada pela introdução de ideias positivistas comtianas, em que a civilização do índio e a sua integração à sociedade nacional tornaram-se urgentes $\mathrm{e}$ indispensáveis devido ao desbravamento do sertão, com a instalação e prolongamento das linhas telegráficas e ferroviárias, e, ainda, ao desenvolvimento da navegação fluvial. Coube ao major Antônio Ernesto Gomes Carneiro e depois ao marechal Cândido Mariano da Silva Rondon empreender a conquista do território nacional por meio da colonização indígena. As teses de Comte sobre a evolução da sociedade foram fortemente acolhidas pelos militares dirigentes da nação brasileira a ponto de ter sua expressão na divisa positivista da bandeira nacional com o lema: Ordem e Progresso. Segundo Cuccagna (2004), a contribuição de Sousândrade "é filha desse tempo, dessas tendências filosóficas e dessas exigências de desenvolvimento nacional. De fato [...] ela mantinha pontos de contato com a abordagem positivista que, ao problema do índio e da sociedade em geral, se tentava dar durante a segunda metade do século XIX. Ou melhor, poder-se-á sem dúvida afirmar que os conceitos de 'civilização' e de 'progresso' estiveram sempre imanentes a todo o projeto indigenista e republicano sousandradino" (CUCCAGNA, 2004, p. 160).

\section{Referências}

ARISTÓTELES. Ética a Nicômaco. Tradução de Leonel Vallandro e Gerd Bornheim. São Paulo: Victor Civita, 1973. (Coleção Os pensadores).

. Poética. Tradução de Eudoro de Souza. São Paulo: Nova Cultural. 1987.

CAMPOS, Augusto; CAMPOS, Haroldo. Re visão de Sousândrade. São Paulo: Perspectiva, 2002.

CUCCAGNA, Cláudio. A visão do ameríndio na obra de Sousândrade. São Paulo: Hucitec, 2004.

DUARTE, Sebastião Moreira. A épica e a época de Sousândrade. São Luís: AML, 2002.

JAKOBSON, Roman. Linguística e comunicação. Tradução de Izidoro Blikstein e José Paulo Paes. São Paulo: Cultrix, 2006.

RICOEUR, Paul. $O$ conflito das interpretações: ensaios de hermenêutica. Tradução de 
M. F. Sá Correia. Porto, Portugal: Rés-Editora, 1988.

. Du texte à l'action. Paris: Seuil, 1986.

. Temps et récit. I. Paris: Seuil, 1983.

. Temps et récit. II. Paris: Seuil, 1984.

. Temps et récit. III. Paris: Seuil, 1985.

. La métaphore vive. Paris: Seuil, 1975.

SAUSSURE. Ferdinand de. Curso de Linguística Geral. Tradução de José Paulo Paes e Izidoro Blikatein. São Paulo: Cultrix, 2006.

SOUSÂNDRADE, Joaquim de. O Guesa. Organização de Jomar Moraes e Fredericg G. Williams. São Luís: AML, 2003. 